\title{
Greeks seek to balance funding from Brussels
}

Athens. The European Commission (EC) has taken over from the national government as the largest single sponsor of Greek research. In 1986, five years after Greece joined the European Union (EU), money from abroad was equal to only three per cent of government spending on research and development; by 1991, almost a third of research funds came from the EC alone.

The Greek government, which has deliberately set out to use the EC as a major source of research funding, is unembarrassed by this trend. "Brussels has helped us create our critical mass of scientists and improve the quality of our research," says the secretary-general for research and technology, Nicos Christodoulakis.

But some scientists fear that the result could be damaging for both Greek science and the country. They are urging the government to channel more domestic funding into research if it wants to secure its future.

Greece spends less on research -0.45 per cent of its gross national product - than any other country in the EU. But it receives one of the highest levels of research funding from the EC in relation to its size.

In addition to 'structural' funds, which are distributed to governments of poorer EU countries to improve their infrastructure and can be used to create research facilities, Greece won 3.6 per cent of the money distributed under the EC's third Framework programme, covering the period 1989-93. This is three times higher than the proportion of the Greek population within the EU, and six times higher than the proportion of scientists working in Greece.

$$
\text { As a result, }
$$

many individual research institutions have become heavily dependent on the EC. More than half of the total budget of the Institute of Molecular Biology and Biotechnology (IMBB) in Crete, for example, comes from Brussels.

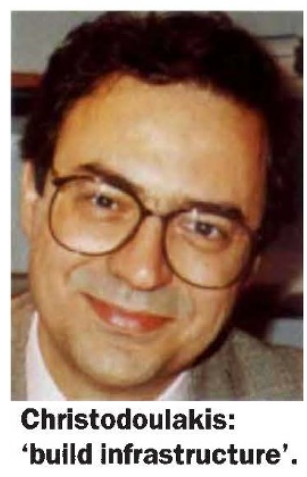

Researchers at the institute acknowledge that, without such support, the institute itself would probably never have been built. But there is resentment about the extent to which its fortunes depend on an agenda set in Brussels. "We sometimes feel we are simply working on contract for the EC," says director George Thireos.

\section{EC backs industrial studentships}

Athens. Keen to promote tighter links between research and industry, the Greek government has, with backing from the European Commission (EC) in Brussels, just launched a joint $\mathrm{PhD}$ programme which will fund 500 studentships with a strong industrial bias.

Greek industry has one of the lowest expenditures on research in Europe, providing only a quarter of the country's total spending on research. The government has been trying to encourage industry to make more use of scientific results. But the effort has been small-scale, and hampered by the low level of industrial activity in Greece's predominantly rural economy, as well as the lack of an indigenous tradition of industrial innovation.

Isolated efforts have been made to improve this situation. The Foundation for Research and Technology Hellas (FORTH), for example, set up seven research institutes in the 1980 s with the intention of turning the results of their basic research into marketable products.

This has had some success. In Crete, for example, the Institute for Molecular Biology and Biotechnology (IMBB) manufactures and sells restriction enzymes, oligonucleotides and immunodiagnostic kits. But only the immunodiagnostic division has so far been converted into a spin-off company. "A major problem we face is the low demand for R\&D by Greek industry " says FORTH director Eleftherios Economou.

Now, in order to improve the overall situation, the government has drawn up a four-point plan which it hopes will be funded through the structural funds of the European Union. One element is the new $\mathrm{PhD}$ programme, which will cost ECU9.5 million over six years.

In addition, plans for four technology parks will be completed by creating liaison offices at each. The general secretariat for research and technology will also help to finance the setting up of a number of private institutions to help Greek companies to acquire foreign technology. And a number of bureaux will be set up to bring together industry and researchers.

The government's determination to make science serve the economy is underlined by its decision to restrict all new research grants to applied research. But demic community, worried that the country's basic research base will be severely weakened. "The EC does not give money to investigate brand new research," says George Thireos, director of the IMBB. "We need seed money from the government if we are to have a future."

Alison Abbott this move is being contested by the aca-
Similarly most project money at the two biggest research institutions in Athens the Demokritos research centre and the $\mathrm{Na}$ tional Hellenic Research Foundation (NHRF) - also originates in Brussels. "For Greece, EC funding is not the cherry on the cake, but the cake itself," says Ion Siotis, director of nuclear physics at Demokritos.

Panagiatis Manakos, the director of Demokritos, points out that as a result most of the government's domestic spending on research is used to match EC funds. This, he says, prevents Greece from developing a national science policy of its own.

$\mathrm{He}$ also complains that Greece has few plans to sustain investments made by the EC. For example, more than ECU1 million of structural funds were used to build a library at Demokritos. But the centre does not receive any government support for journal subscriptions. Others point out that Greece, like other small EU countries, has a small voice in shaping EU research policy.

But the pleas of the scientific community find little echo in government corridors, where EC support is acknowledged to have played a significant part in building up the country's research infrastructure. Christodoulakis sees little point in raising domestic funding for research until this infrastructure is improved still further.

Of greater concern to the general secretariat is the fact that the domestic provision of matching funds has recently been cut back severely. In 1992, the government provided sufficient funds to match all those received from the $\mathrm{EC}$; but last year it matched only 10 per cent of EC grants.

As a result, recipient research centres have had to find the money from elsewhere, and often admit to having used 'creative accounting' to meet EC regulations. The secretariat is keen to change this situation, and has now asked for a share of the economics ministry's reserve funds to make up the difference.

Alison Abbott

\section{French back EU efforts on research}

Paris. Officials in the research and environment directorates of the European Commission have been cheered by the results of a survey on attitudes towards the European Union (EU) carried out by the French newspaper Libération. This revealed that almost three-quarters of the French population approve of the EU's policies on research.

The survey, whose results were published last week, showed that 53 per cent felt similarly about EU environment policy. In contrast, two-thirds of those questioned felt that EU policies on employment and agriculture are going in the wrong direction. $\square$ 